Relations industrielles

Industrial Relations

\title{
Work Stress and Coping in the Era of Globalization, by Rabi S. Bhagat, James C. Segovis and Terry A. Nelson, New York: \\ Routledge, 2012, 308 pp., ISBN: 978-0-805804847-2.
}

\section{Judy Haiven}

Volume 68, numéro 4, automne 2013

URI : https://id.erudit.org/iderudit/1023013ar

DOI : https://doi.org/10.7202/1023013ar

Aller au sommaire du numéro

Éditeur(s)

Département des relations industrielles de l’Université Laval

ISSN

0034-379X (imprimé)

1703-8138 (numérique)

Découvrir la revue

Citer ce compte rendu

Haiven, J. (2013). Compte rendu de [Work Stress and Coping in the Era of Globalization, by Rabi S. Bhagat, James C. Segovis and Terry A. Nelson, New York: Routledge, 2012, 308 pp., ISBN: 978-0-805804847-2.] Relations industrielles / Industrial Relations, 68(4), 711-713. https://doi.org/10.7202/1023013ar

Tous droits réservés (C Département des relations industrielles de l’Université Laval, 2013
Ce document est protégé par la loi sur le droit d'auteur. L'utilisation des services d'Érudit (y compris la reproduction) est assujettie à sa politique d'utilisation que vous pouvez consulter en ligne.

https://apropos.erudit.org/fr/usagers/politique-dutilisation/ 
de façon fructueuse lorsque les principes marchands dominent.

On ne peut que féliciter ces pionnières et pionniers d'avoir eu le courage d'entreprendre de telles expériences sans garantie de réussite, de les avoir évaluées sans complaisance et de partager leurs interrogations. Les deux coordonnatrices ont accompli un travail titanesque dont les lecteurs et lectrices leur seront reconnaissants. La qualité de l'ouvrage mériterait qu'on s'attarde plus longuement aux questions de fond soulevées tout au cours du volume. Ce que pourront faire, nous l'espérons, celles et ceux qui souhaitent s'initier à l'analyse critique du travail et aux actions qui en découlent.

\section{Hélène David}

Université de Montréal

\section{Work Stress and Coping in the Era of Globalization}

by Rabi S. Bhagat, James C. Segovis and

Terry A. Nelson, New York: Routledge, 2012, 308 pp., ISBN: 978-0-805804847-2.

In the library at Saint Mary's University, there are 174 books and government documents under the subject heading "workplace stress." All of them address the growing phenomena of stress in the Canadian or US workplace. A handful of the books are concerned about workers' stress in the UK, and one book is about the situation in France. Not one ventures into the area of how globalization affects workplace stress in other cultures and other countries. This is what Work Stress and Coping in the Era of Globalization is all about. This book warns that there are vast human consequences of workplace stress - and that companies throughout the world are coping, or not coping, rather differently than many of us think. Work Stress is a truly remarkable book written by three American academics who take a keen interest and have special insight into culture and the developing world.
The book begins with a definition of globalization which the authors tracked back as far as 1951: "...the most widely understood connotation was on the spread of the global economy to regional economics around the world" (p. 1). This definition seems almost benign, but the authors tack on the notion of a "...strong interconnectedness among various countries, companies and people located in dissimilar countries and cultures" (p. 11).

The book shows that the world's differing cultures promote very different narratives, symbols, art and generate different social conditions (p. 36). Some interesting observations include:

- Plays and films produced in Germany are three times more likely to have tragic endings than those from the US and India (p. 36).

- In Paris, couples having coffee in cafés were observed touching 110 times on average; in San Juan, Puerto Rico, they touched 180 times, yet in the UK couples rarely touched each other in public (p. 36).

- $65 \%$ of Japanese worry about saying the wrong thing in a social environment compared with only $25 \%$ of Americans (p. 36).

A cultural example, in Nova Scotia, is that one large US-based corporation asked its Halifax staff to trade their July $1^{\text {st }}$ holiday for the American July $4^{\text {th }}$ holiday - so that the Canadian office would be in step with the US headquarters.

These might seem like small things, but the book notes that while changing holidays might not provoke much hostility, most workers live in the shadow of possible layoffs, downsizing, reduced wages, discrimination, or weakening of trade union rights. In the face of these stressors, workers become (justifiably) angry. The question is: how do people's cultures and ways of handling stress play into their reactions to serious workplace problems? For example, 
Work Stress notes the typical western strategies used to manage and sometimes prevent the onset of stress in the workplace. The authors also draw attention to old tropes that are bad science and even dangerous which are presented as prescriptions to workplace stress. For example, frustrated workers at giant factories in China are encouraged to hit punching bags, inflatable dolls or even take sledgehammers to junked cars in what is called "destructotherapy" (p. 90-91).

One company, worried about the high suicide rate among its office employees, built a room with punching bags. But as one journalist remarked, "Perhaps if companies like Foxconn are worried about employees leaping to their deaths from office buildings, they would be better to build suicide barriers outside windows rather than aggression rooms inside them" (p. 91).

The book's authors take issue with stress management interventions which have been categorized as primary (for the least serious problems), secondary and tertiary (the most serious). At the primary level, management tends to use job redesign, sharing workload, improving work schedules, and reducing role conflict - among other "fixes" - in attempts to reduce workers' stress. At the secondary level, management tries to create a better "fit between a person and the environment as well as ... transactions with the environment" (p. 97). To this end, management might improve training, institute a corporate "wellness" program and suggest employees seek counselling through the company's EAP (Employee Assistance Program). The tertiary interventions are usually geared to the individual who is referred to EAP for oneon-one therapy to address the employee's personal problems and improve his or her's "emotional damage control" (p. 99).

However, as stated earlier, authors Bhagat, Segovis and Nelson take issue with these interventions. They criticize them for being "dominated by an individual perspective" (p. 101) rather than looking at the wider society and the world of work for answers. The book notes that in many countries the secondary and tertiary interventions simply do not work: "In China, India, Turkey, Mexico, Vietnam, Indonesia and many countries of Latin America and Africa, seeing a professional counsellor or therapist on a regular basis for managing work stress and symptoms of strains is not a culturally viable option. Not only would the cost of such services be rather high, but one would also risk losing one's reputation" (p. 154).

Another objection to the conventional approach is that today's workplaces tend to look at the toll created by distress (bad stress) rather than acknowledging the role of eustress (good stress). Finally, the authors think western researchers tend to ignore the role that culture, spirituality or even religion plays as a potential coping strategy. Stress management mechanisms in China, for example, include dependence on the social network called guanxi relationships (p. 155) which stress the role of mutual obligations, and doing favours for some people and family members. Eating communally and playing games are also considered stress relievers in the Chinese culture.

Of course understanding cultural differences is a necessity in Canada as nearly a quarter of a million people immigrate here every year, and there are more than 330,000 temporary foreign workers. In the 2009, Hispanics became the largest ethnic group in the US, surpassing African-Americans by nearly $50 \%$ (p. 187-188). The book details the Hispanic-American and the AfricanAmerican experience of work stress, as well as examining other cultural groups and religious minorities who identify differently from the mainstream. For example, in many countries controversies continue to swirl over the right of Muslim women to wear the hijab, the niqab and the burqa. Many people believe that banning these 
constitutes an attack on a person's religion or freedom of conscience. However France forbids girls or women wearing the hijab in all public schools. Closer to home in Quebec, the government's Bill 94 attempted to restrict women's right to wear the veil when accessing government services, such as schools or hospital care.

In conclusion, Work Stress argues that prior to 1980 there was no great need to look at workplace stress and coping until globalization started to expand. The book explains many Western and non-Western attitudes toward workplace stress and its effect on people and organizations. And, as the authors hint, with the precipitous rise of globalization, the situation will only get worse.

\section{Judy Haiven}

Saint Mary's University

\section{The Psychology of Assessment Centers}

edited by Duncan J. R. Jackson, Charles E. Lance and Brian J. Hoffman, New York: Routledge, 2012, 360 pp., ISBN: 978-0-41587814-2.

For those who are new to the term, "assessment centre" is something of a misnomer, referring less to a place than a method of bringing together multiple assessments of individuals in order to determine their value for an organization. The purpose of assessment centres can vary, including selection, promotion and professional development, but the integration of multiple assessments, including behavioural ratings and cognitive and personality assessments, obtained from multiple sources such as self, peer and observer ratings, is typical. As such, few individual activities in human resource management and employment relations better encapsulate the complexity of organizations and their interaction with staff than do assessment centres. Almost the full range of issues to do with managing people can be found here, complete with conflicting views on the meaning of guid- ance and performance, along with active impression management by all parties, compounded by recognition and rewards provided amidst multifarious implicit and explicit promises and expectations, all within a context of legal and quasi-legal extra-organizational requirements. Assessment centres have it all.

The editors of this book chose to make this more manageable by deliberately adopting a measurement paradigm within an organizational psychology perspective. Considered from within this point of view, the range of authors and topics is hard to fault - indeed, Charles Lance and Brian Hoffman seem to be self-evident choices as both editors and authors. Apart from these, researchers with strong track records have been included (e.g., Filip Lievens and Winfred Arthur Jr.) along with two of the biggest names in psychological research on work performance in the last few decades, Paul Sackett and Walter Borman, who top and tail the collection. These over-performers in organizational psychology research are supported by a strong range of researchers and research-informed practitioners. Nonetheless, it would have been good to also have input from Frank Schmidt and Kevin Murphy and their colleagues, given that their views on measurement are entirely pertinent to measurement issues within assessment centres, about which more is discussed later in this review.

Sackett's Foreword contextualized the volume using an issue that Sackett himself helped to highlight (Sackett and Dreher, 1982), specifically the role of exercises and dimensions in accounting for variance in post-exercise dimension ratings (PEDRs) and overall assessment centre ratings (OARs). The editors used these components of measurement variance within assessment centre ratings to guide discussion and provide structure to the volume, after the introductory, scene-setting chapters.

The introductory chapters are generally quite informative, beginning with a useful 